\title{
Research on Teaching Reform of High-quality Courses of College Physical Education in the Era of Big Data
}

\author{
Baofa $\mathrm{Ma}^{1, *}$ Tienan $\mathrm{Wu}^{1} \mathrm{He} \mathrm{Sun}^{1}$ \\ ${ }^{1}$ Heihe University, Heihe, Heilongjiang 164300, China \\ "Corresponding author. Email: 15261689@qq.com
}

\begin{abstract}
The construction of high-quality courses is a forward-looking and important measure for China's colleges and universities to deepen the teaching reform and improve the teaching level and quality of undergraduate courses, and also has become an important work of colleges and universities with iconic value. Viewing the status quo of the construction of high-quality courses of physical education in ordinary colleges and universities, this paper discusses the current problems encountered in the construction of high-quality courses of physical education and puts forward suggestions, trying to provide a reference for the further construction of national high-quality courses of physical education.
\end{abstract}

Keywords: College physical education, High-quality courses, Teaching reform.

\section{INTRODUCTION}

Against the background of big data, college physical education teaching has shown more characteristics of the new era. At the same time, with the development of big data, there are more requirements for the evaluation system of college physical education. Under such an environment, college physical education should take a series of reforms and face challenges based on the requirements of the new era. Physical education is an important part of education. Physical education curriculum is one of the basic links to ensure the quality of talent training in schools, and is also the curriculum with the largest coverage and the most benefited students in the teaching system. In order to adapt to the development strategy of rejuvenating the country through science and education and emphasize the education in the new era, the reform of physical education teaching has been continuing for many years and has achieved initial results. The nationallevel high-quality course of physical education

*Fund: 2020 Higher Education Teaching Reform Project"Research on the Teaching Reform of High-quality courses of college physical education in the Era of Big Data" (SJGY20200480). announced by the Ministry of Education is one of the signs of high-level physical education in schools.

\section{THE SIGNIFICANCE OF CONSTRUCTING HIGH-QUALITY COURSES OF PHYSICAL EDUCATION}

The reform of curriculum system, teaching content, teaching methods and means is not only the core of college physical education teaching reform, but also the key and difficult point of college physical education teaching reform.

By constructing high-quality courses of physical education, colleges can further optimize the system of physical education courses, improve the ability of college students to learn actively and autonomously, and seek benefits and health. At the same time, through research, construction and practice, the ability of teachers to carry out quality education is constantly improved, so as to improve the quality of physical education teaching. 


\section{CONTINUOUSLY CARRYING OUT EFFECTIVE INTEGRATION OF COURSE CONTENT AND COURSE STRUCTURAL SYSTEM TO HIGHLIGHT THE CHARACTERISTICS OF HIGH- QUALITY COURSES}

The development of "College Physical Education" in colleges and universities should have enough breadth, ladder and depth, and at the same time, it should highlight the modern requirements of comprehensiveness and diversification, openness and selectivity in teaching practice. In order to realize the high-quality course of college physical education, colleges strive to take the students as the center, popularize and implement personalized teaching, constantly strengthen the role of college physical education in the whole teaching work, and further implement innovative ideas in the course teaching. The high-quality course[1] "College Physical Education" has been set for several consecutive years. In order to enable students to continuously enjoy the college physical education teaching mode of physical health education, it is necessary to fundamentally change the curriculum education mode focusing on competitive sports, and gradually form a curriculum content practice mode taking college physical education classroom teaching as the center, high-level sports teams with high-quality brands as the leader and student group fitness as the basic goal, deeply popularize the awareness of lifelong physical fitness and improve the practicality and efficiency of college physical education classroom teaching. And students can complete the task of physical education course of nearly 180 class hours in several years[2].

The courses are as follows: theoretical courses of college physical fitness, courses on methods and practical application of college physical fitness skills, physical exercise training courses, and physical fitness rehabilitation and limb health care courses. Among them, the teaching objects of theoretical courses of college physical fitness and courses on methods and practical application of college physical fitness skills are the teachers and students of the university, including high-level professional athletes. The teaching objects of physical exercise training courses are mainly highlevel athletes in the school and some special students participating in sports training in university clubs. The physical fitness rehabilitation and limb health care courses are mainly aimed at the rehabilitation training of special groups of college students with physical defects and disabilities.

\section{ADAPTING TO THE NEEDS OF FUTURE SURVIVAL AND DEVELOPMENT AND PAYING ATTENTION TO THE CULTIVATION OF STUDENTS' PSYCHOLOGICAL QUALITY}

Psychological quality refers to a person's psychological bearing capacity to the future society. Under the condition of modern market economy, the competition between professional and technical practitioners is becoming increasingly fierce. This kind of competition appears to be the competition of knowledge, ability, intelligence, technology and body, as well as the competition of psychological quality. Modern science and technology are changing with each passing day[3]. Practitioners should constantly learn new science and technology and have a positive and enterprising sense of competition, indomitable sense of quality and good psychological quality, and then they can better cope with challenges and win survival and development in the ever-changing career competition. In the physical education teaching of colleges and universities, colleges and universities should not only exercise the physical quality of students, but also focus on cultivating students' competitive consciousness, fighting spirit, indomitable sense, unity and cooperation spirit, and pay attention to the cultivation of students' psychological quality according to the characteristics of the learned sports, and cultivate high-quality technical talents with physical and mental health for the society.

\section{STRENGTHENING ADAPTIVE PHYSICAL TRAINING AND CULTIVATING COLLEGE STUDENTS' PHYSICAL ADAPTABILITY TO FUTURE WORK}

Adaptive physical training is the physical training of students through the forms, means and methods of specific items in physical education teaching in colleges and universities. The organic combination of athletic ability and adaptive labor physical fitness can be achieved, laying the physical foundation for the future work. With the development of modern science and technology, the automation and specialization of enterprises are constantly improving. Due to the high efficiency of 
production, the physical requirements of workers are also getting higher and higher. Therefore, it is required to carry out physical exercise in college physical education teaching with the purpose, so as to adapt to the characteristics of future work[4]. And then, students' physical fitness can be effectively enhanced, the occupational diseases will be avoided, so as to meet the physical requirements of workers in the future work. Many sport events can be internalized into the students' physical exercise, such as durability, quick reaction capability, body coordination ability, attention and observation. Many jobs have essential physical requirements for workers, and this requirement can be trained through physical education in schools.

\section{STRENGTHENING THE TRAINING OF TEACHERS AND THE CONSTRUCTION OF QUALIFIED PERSONNEL TEAM}

The key to the construction of high-quality courses is to have a team of young and vigorous teachers with high academic level and reasonable structure. The construction of high-quality courses relies on the education and teaching level of famous teachers and reflects the wisdom, experience and personality charm of famous teachers. Therefore, the first task of the construction of high-quality courses is to build a team of high-level teachers. Teachers are the implementers of curriculum construction and the core elements of curriculum. Through the construction of high-quality courses, a team of teachers with reasonable professional title structure, high teaching level, excellent teaching quality and strong sense of responsibility has been gradually formed, as well as course leaders with good quality, strong dedication and high scientific research level. In this process, it is necessary to pay attention to three aspects: the construction of course leader and lecturers, the construction of teaching team structure and overall quality, the teaching reform and teaching research of the curriculum team. In view of the lack of high-level academic leaders of physical education in some schools, the combination of introduction and training methods can be adopted. At the same time, colleges and universities can encourage young and middle-aged teachers to make further study and training for degrees, so as to improve the overall level. In order to build a team of teachers with extensive knowledge, excellent professional ability and strong scientific research ability, it is necessary to put investment in capital and time. For example, it is required to provide necessary conditions for the introduction of talents and the postgraduate entrance examination of young teachers. Only by establishing a team of high-quality physical education teachers can we complete the tasks entrusted by the education and teaching reform.

\section{REFORMING TEACHING CONTENTS AND METHODS}

The construction of teaching content is the core of high-quality course construction. The essence of high-quality course is embodied in the content of the course. The content of high-quality courses should be advanced, practical and interesting. In addition, it is necessary to reflect the latest scientific research achievements, absorb advanced teaching experience, integrate excellent teaching results actively, and reflect the requirements put forward by present society, politics, economy, science and technology and so on for talent training. The high-quality physical education courses in colleges and universities must highlight the comprehensiveness, pertinence and application of teaching content. Also, it is better to break the traditional physical education teaching mode with competitive sports as the content and quality and skills as the goal, establish a new physical education teaching system with lifelong physical education consciousness as the content and students' physical and mental health as the goal, change the single curriculum teaching mode, and build an open, life-oriented, socially interesting and vibrant physical education teaching model with the trinity of classroom teaching, extracurricular activities and sports training. It is of great significance to enhance the quality of students and cultivate their lifelong sports consciousness, as well as their spirit of struggle, innovation, enterprising, struggle and high sense of responsibility and honor.

The fundamental purpose of the reform of teaching methods and means is to improve teaching quality and teaching effect. Colleges and universities should change the competitive sports system that has been followed for many years, and create a new teaching method according to the physical and mental characteristics of students and the needs of lifelong sports. In addition to the traditional teaching method, demonstration method and practice method, it is suggested to add question and answer method, discussion method, case method, inspection method, game method, etc. At the same time, it is better to apply multimedia technology to physical education, develop a campus network platform, form a teaching mode inside and 
outside the class, realize the sharing of high-quality resources, give full play to the curriculum characteristics of the information age, and transform the traditional teacher-led and indoctrinated teaching method into a new teaching mode with students as the main body and teachers as instructors. In addition, teachers should give students autonomy and opportunities for innovation, combine theory with practice and integrate in-class and out-of-class. For the future career and lifelong sports training, colleges should set up some new optional courses of sports and health lectures with sports health care as the content, and change the methods of sports performance assessment.

\section{STRENGTHENING THE CONSTRUCTION OF SPORTS VENUES AND HIGH-LEVEL TEACHING MATERIALS}

The teaching environment is an important guarantee for the completion of teaching tasks and the implementation of teaching plans[5]. The improvement of stadiums and sports equipment is not only an important content of optimizing the physical education teaching environment, but also the basis and guarantee of the construction of highquality physical education courses, which plays an indispensable role in the development of physical education teaching and sports training, and is necessary for the construction of high-quality physical education courses. In recent years, colleges and universities have invested a lot of funds in sports infrastructure construction. The newly-built and expanded stadiums and gymnasiums provide resource guarantee for the construction of high-quality physical education courses. Due to the expansion of enrollment in colleges and universities, there are few sports resources per capita. Some colleges and universities do not have indoor gymnasiums and lack sports equipment that meet national quality standards and safety norms. All these require colleges to invest more funds and strengthen the hardware construction of high-quality courses. Teaching materials are the basis for teachers to engage in teaching. Teaching materials are compiled according to the syllabus, which reflects the teaching purpose and training objectives. Highquality courses must be assisted by excellent physical education teaching materials. The use and compilation of excellent teaching materials can promote the overall improvement of teaching quality and highlight the advantages and characteristics. The optimization of teaching content should finally be reflected and implemented in the teaching materials. At present, many textbooks have outdated content, backward system and similar structure. Therefore, it is unable to form high-quality physical education textbooks. Therefore, in order to form high-quality teaching materials, it is necessary to focus on talent training objectives and teaching requirements, reflect Deng Xiaoping's teaching theory of "three orientations", establish a subject curriculum system with lifelong physical education as the core, and confirm the contents of relevant teaching materials. Highquality course materials should be jointly prepared by the physical education teachers and sports experts of colleges and universities. The textbooks in colleges and universities should accurately reflect the training objectives and requirements of higher education, do not seek the integrity and comprehensiveness of theory, but emphasize practicality, advancement and operability, so that students are willing to accept and easy to use, benefit for life. Such textbooks can be regarded as high-quality course textbooks.

At the same time, it is necessary to establish and perfect effective management system, which is the guarantee to ensure the smooth development of teaching work and achieve teaching objectives. High-quality course is a high-level demonstration course. To give full play to its "high-quality" role, first-class teaching management is the premise to ensure the smooth implementation of high-quality course construction. The teaching management of the school involves the management of administrative personnel, teachers, students, logistics service personnel, etc. First of all, it is required to clarify the responsibilities of all kinds of personnel, establish rules and regulations, and use systems to regulate behaviors. These systems are involved in teaching administrative work management, teaching staff management, and student status management, teaching materials management, teaching and research management, teaching evaluation management, sports competition management, teaching equipment management, logistics service management and so on. These rules and regulations are compiled into a volume, promulgated and implemented, so that the teaching management has rules to follow and enters the management track of standardization, institutionalization and legalization[6]. The development and application of teaching management software indicates that teaching management has changed from traditional manual 
management to intelligent management. Some school teaching management has realized informatization and networking.

\section{CONCLUSION}

The units that can win the title of national highquality courses have their own advantages in terms of teaching. Under the effective radiation and demonstration of their own open and invested construction resources, they have made more achievements in promoting the development and construction of high-quality courses in other application units, but they are generally lack of network teaching development. With the help of network assisted teaching platform, it will be the most powerful impetus to the physical education theoretical curriculum guidance and future development trend of teaching in colleges and universities.

\section{AUTHORS' CONTRIBUTIONS}

Baofa Ma analysed data, Tienan $\mathrm{Wu}$ wrote the manuscript, and He Sun contributed to revising and editing

\section{REFERENCES}

[1] Qin Yong. Suggestion on Teaching Quality Improvement of College Physical Education [J]. Journal of Henan Institute of Education (Natural Science Edition) 2010(1). (in Chinese)

[2] Wang Weilin, Shu Chuan. The Practice and Research of Soccer Exguisite Course Teaching Content of the Construction in University [J]. Journal of Gannan Normal University 2010(6). (in Chinese)

[3] Yang Ming. A Consideration on Balanced Development of Internet Resources of College Physical Education [J]. Theory and Modernization 2011 (1). (in Chinese)

[4] Zhang Dengfeng. Study on Construction of National High-Quality Sports Courses [J]. Sports Culture Guide 2010(4). (in Chinese)

[5] Ren Yong. Conception on the Teaching Design for students'P.E Qualities in General Colleges [J]. Journal of Harbin Institute of Physical Education 2008(6). (in Chinese)

[6] Xie Dongxing. Analysis on the selection of superior items for private colleges and universities to construct excellent sports courses [J]. Journal of Chifeng University (Natural Science Edition) 2009. (in Chinese) 